\title{
An unusual case of bilateral peroneal palsies due to fabellae
}

\section{Figure $\quad$ MRI and high-resolution ultrasound findings}
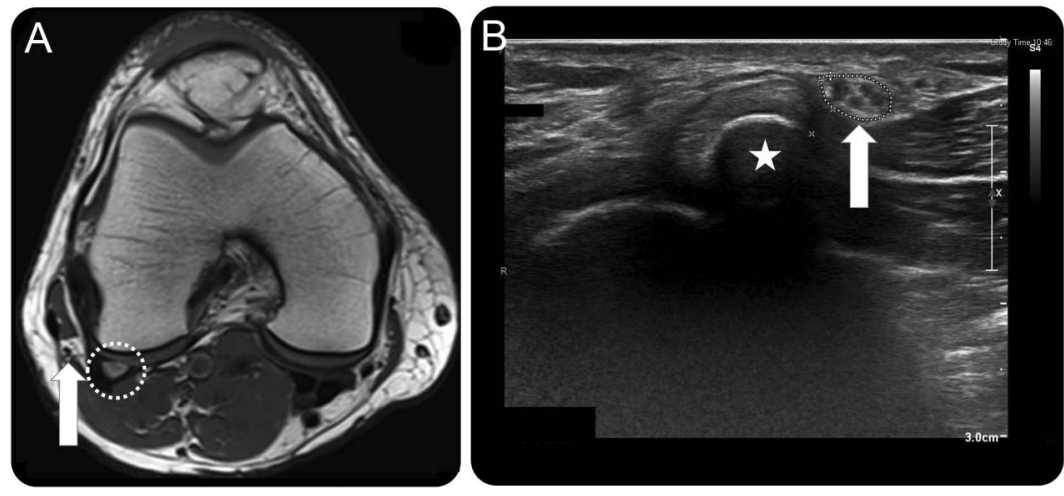

While MRI (A) in the extended knee position did not show a close spatial relation between fabella (circle) and peroneal nerve (arrow), high-resolution nerve ultrasound (B) in semi-flexed knee position displayed the peroneal nerve (arrow) in direct proximity to the fabella (star). Only images of the right side are shown.

A 28-year-old otherwise healthy man presented twice with a peroneal nerve palsy, first on the left and 4 months later on the right side. Both palsies occurred after sitting on a chair for a few hours. Personal and family history were unremarkable. Electrophysiologic examinations revealed conduction blocks of the peroneal nerves slightly above the fibular head and signs of acute denervation in the anterior tibial muscles. Bilateral fabellas (sesamoid bones) within the tendon of the lateral head of gastrocnemius muscles detected by ultrasound and MRI (figure) caused these unusual pressure palsies. ${ }^{1}$ Surgical excision of the fabellae resulted in full recovery.

Bernhard F. Décard, MD, Sara Nagy, MD, Meritxell Garcia, MD, Peter Fuhr, MD

From University Hospital Basel, Switzerland.

Author contributions: B.F.D., S.N., M.G., and P.F. were involved in the neurologic patient care and analysis and interpretation of clinical results and data. B.F.D. drafted the manuscript. M.G. and P.F. revised the manuscript.

Study funding: No targeted funding reported.

Disclosure: The authors report no disclosures relevant to the manuscript. Go to Neurology.org for full disclosures.

Correspondence to Dr. Décard: bernhard.decard@usb.ch

1. Cesmebasi A, Spinner RJ, Smith J, Bannar SM, Finnoff JT. Role of sonography in the diagnosis and treatment of common peroneal neuropathy secondary to fabellae. J Ultrasound Med 2016;35:441-447. 


\section{Neurology}

\section{An unusual case of bilateral peroneal palsies due to fabellae \\ Bernhard F. Décard, Sara Nagy, Meritxell Garcia, et al. \\ Neurology 2017;88;918 \\ DOI 10.1212/WNL.0000000000003666}

This information is current as of February 27, 2017

\section{Updated Information \& Services}

References

Subspecialty Collections

Permissions \& Licensing

Reprints including high resolution figures, can be found at: http://n.neurology.org/content/88/9/918.full

This article cites 1 articles, 1 of which you can access for free at: http://n.neurology.org/content/88/9/918.full\#ref-list-1

This article, along with others on similar topics, appears in the following collection(s):

All Clinical Neurology

http://n.neurology.org/cgi/collection/all_clinical_neurology EMG

http://n.neurology.org/cgi/collection/emg

MRI

http://n.neurology.org/cgi/collection/mri

Peripheral neuropathy

http://n.neurology.org/cgi/collection/peripheral_neuropathy Ultrasound

http://n.neurology.org/cgi/collection/ultrasound

Information about reproducing this article in parts (figures,tables) or in its entirety can be found online at:

http://www.neurology.org/about/about_the_journal\#permissions

Information about ordering reprints can be found online:

http://n.neurology.org/subscribers/advertise

Neurology ${ }^{\circledR}$ is the official journal of the American Academy of Neurology. Published continuously since 1951, it is now a weekly with 48 issues per year. Copyright @ 2017 American Academy of Neurology. All rights reserved. Print ISSN: 0028-3878. Online ISSN: 1526-632X.

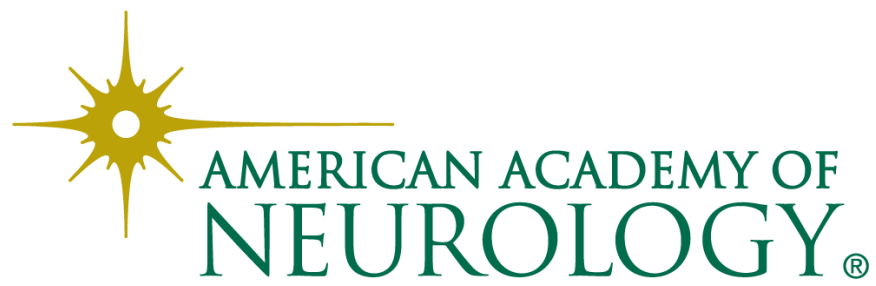

